\title{
Bacterial species recognized for the first time for its biocontrol activity against fire blight (Erwinia amylovora)
}

\author{
Artur Mikiciński - Joanna Pulawska (D) Assel Molzhigitova • \\ Piotr Sobiczewski
}

Accepted: 25 October 2019/Published online: 14 November 2019

(C) The Author(s) 2019

\begin{abstract}
This study included eight bacterial isolates originating from the apple phyllosphere or soil environment that were previously selected using the pear fruitlet test (Mikiciński 2017). Identification of these isolates based on phenotypic assays and DNA analysis showed that five of them belonged to species for which an antagonistic activity against Erwinia amylovora and the protective capacity of apple and pear against fire blight were not previously demonstrated. These were L16 identified as Pseudomonas vancouverensis, $3 \mathrm{M}$ as Pseudomonas chlororaphis subsp. aureofaciens, $35 \mathrm{M}$ - Pseudomonas congelans, $43 \mathrm{M}$ - Enterobacter ludwigii, and $59 \mathrm{M}-$ Pseudomonas protegens. Investigation of the biotic relationships between the tested strains and E. amylovora showed that $3 \mathrm{M}, 35 \mathrm{M}$ and $59 \mathrm{M}$ inhibited the growth of the pathogen on five out of six media used (NAS, KB, LB, R2A, NAG), but $43 \mathrm{M}$ did not do so on any of these media. Strain L16 did not inhibit the growth of the
\end{abstract}

A. Mikiciński · J. Puławska • P. Sobiczewski $(\bowtie)$

Research Institute of Horticulture, Skierniewice, Poland

e-mail: piotr.sobiczewski@inhort.pl

\section{A. Mikiciński}

e-mail: artur.mikicinski@inhort.pl

J. Puławska

e-mail: joanna.pulawska@inhort.pl

A. Molzhigitova

al-Farabi Kazakh National University, Almaty, Kazakhstan

e-mail: assel.ermekkyzy@mail.ru pathogen on $\mathrm{LB}$ or R2A medium. In contrast, all strains grown on medium 925 stimulated the growth of the pathogen, which showed no growth without cocultivation with these strains. The experiments on apple trees and detached apple branches showed the ability of the tested bacteria to protect flowers at medium to high levels, depending on the experiment (55-93\%). In some cases, this protection was even higher than that of the copper product used for comparison. In studies assessing the bacterial ability to protect shoots of M.26, the highest efficacy was observed for strains $35 \mathrm{M}(96 \%)$ and $43 \mathrm{M}$ (93\%) but on 'Gala Must' all tested strains showed $100 \%$ of efficacy.

Keywords Biocontrol - Antagonistic bacteria . Pseudomonas vancouverensis $\cdot$ Pseudomonas chlororaphis subsp. aureofaciens · Pseudomonas congelans $\cdot$ Enterobacter ludwigii $\cdot$ Pseudomonas protegens

\section{Introduction}

Fire blight (Erwinia amylovora) is one of the most harmful diseases in apple and pear orchards and nurseries (Vanneste 2000). Observations of its occurrence in Poland showed irregularity in terms of both its severity in regions where it has been recorded for years and its unexpected appearance in regions where it has never been detected. The flowering of host plants is the most endangered 
period because there may be a mass infection of flowers, resulting in disease epidemics (Thomson 2000).

Protection of plants against fire blight includes the use of chemical, agrotechnical, biological, and quarantine methods (Psallidas and Tsiantos 2000; Steiner 2000). Because none of these methods is fully effective, attention is paid to their proper integration (Steiner 2000; Norelli et al. 2003; Sobiczewski 2011). In addition, due to the regulations enforced by the European Union related to the status of E. amylovora as a quarantine organism when it occurs on propagation material (Directive 2000/29/EC), appropriate procedures are needed to eliminate the disease and to prevent its spread. The basic element of fire blight integrated control programmes is inspection of the host plants. Infected parts, or even entire trees or shrubs, should be removed. Cutting tools should be disinfected, and wounds should be protected. In orchards and nurseries at risk of disease, tree growth should be maintained at a moderate level, making them less susceptible. It is also recommended to spray trees with copper compounds that are quite effective at prevention but do not cure plants that are already infected. Copper can also cause side effects in the form of leaf and fruit russets, especially for apple. Additionally, it is worth emphasizing that in the European Union, the use of copper in fruit crops is limited, among others due to its accumulation in the soil environment and unfavourable effects on its inhabiting organisms. In some countries (e.g., the USA, New Zealand, Israel, Canada, Mexico), treatments with antibiotics are recommended (Stockwell and Duffy 2012). However, their use in plant protection within the European Union is prohibited (Fried et al. 2013). To increase the resistance of trees, it is worth considering using prohexadione calcium-based products (Regalis, Apogee) (Norelli et al. 2003; McGrath et al. 2009; van der Zwet et al. 2012). The main purpose of these products is to limit the growth of terminal shoots, but due to the induction of biosynthesis of luteoliflavan, a toxic substance for E. amylovora, the susceptibility of trees to the disease and its harmfulness are significantly reduced (Norelli et al. 2003; Sobiczewski and Bubán 2004). In regions where fire blight is endemic, it is recommended to choose cultivars with higher resistance for new orchard establishment.

In recent years, interest in the search for new methods of disease control, including the use of biological agents, has increased. Based on bacteria antagonistic to E. amylovora, several preparations have been developed and introduced into practice: Bloomtime (Pantoea agglomerans E325, USA), BlossomBless
(P. agglomerans P10c, New Zealand), BlightBan C9-1 (P. vagans C9-1, USA), BlightBan A506 (Pseudomonas fluorescens A506, USA) and Serenade (Bacillus subtilis QST713, USA (Johnson and Stockwell 2000; van der Zwet et al. 2012; Roselló et al. 2013). These preparations are mainly used for apple and pear blossom protection and in programmes integrated with chemical products. Strategies that take into account the use of biological products assume their preventive use with a low or at most medium risk. They are also designated for organic orchards.

As a part of our previous research, we selected the novel strain $49 \mathrm{M}$ of Pseudomonas graminis isolated from the phyllosphere of apple (Malus spp.) showing equal or even higher efficacy in the protection of apple blossoms and terminal shoots than that of the reference strains A506 of Pseudomonas fluorescens and C9-1 of Pantoea vagans, as well as the bioproducts BlightBan A506, Blossom Protect and Hortocyna 18 SP (streptomycin), used for comparison. When strain $49 \mathrm{M}$ was introduced onto apple blossoms in orchards, it effectively colonized them during the entire bloom period, during which there were variable weather conditions, including rainfalls (Mikiciński et al. 2016). Recently, Bahadou et al. (2018) reported new bacterial antagonists from the genera Alcaligenes, Serratia and Brevibacterium, found in Morocco. Research is being conducted to increase the effectiveness of selected strains as well as to find new strains with novel mechanisms of action and higher efficacy (Cabrefiga et al. 2011; Roselló et al. 2013).

The purpose of the present work was to evaluate the efficacy of selected bacterial strains in the protection of apple blossoms and terminal shoots against fire blight and to identify these strains based on phenotypic characters and molecular methods.

\section{Material and methods}

Bacterial isolates/strains and inoculum preparation

Eight bacterial isolates highly effective in fire blight control, selected from the collection of 430 isolates based on the pear fruitlet test (Mikiciński 2017), were used in the study. These isolates originated from both apple leaves (B90, $3 \mathrm{M}, 35 \mathrm{M}, 43 \mathrm{M}, 48 \mathrm{M}, 141 \mathrm{M}$ ) and the soil environment (59 M, L16). The following reference strains were included for comparisons: A506 (Pseudomonas fluorescens) and C9-1 (Pantoea 
vagans), which are active ingredients in biopreparations against fire blight. The strain Ea659 of E. amylovora, originally isolated from apple shoots in Poland, was used for all efficacy trials. All strains were routinely stored in a mixture of PBS buffer with $20 \%$ glycerol at $-70{ }^{\circ} \mathrm{C}$. Bacteria were cultivated on NAS medium (nutrient agar $2.3 \%$, sucrose $5 \%$ ). After $24 \mathrm{~h}$ of incubation at $26{ }^{\circ} \mathrm{C}$, bacteria were washed from the medium with sterile distilled water. Their concentration was adjusted to $1.0 \times 10^{8} \mathrm{CFU} \mathrm{ml}^{-1}$, except for strain Ea659, to $1.0 \times 10^{7} \mathrm{CFU} \mathrm{ml}{ }^{-1}$, using a spectrophotometer (Semco S91E, Germany) at $630 \mathrm{~nm}$ and a dilution plating method on NAS.

Identification of studied isolates

\section{Phenotypic characterization}

The selection of tests to determine the morphological, physiological and biochemical characteristics of the bacteria was made on the basis of the following manuals and keys: Lelliott and Stead (1987), Schaad et al. (2001) and Janse (2005). The following features were determined: colony morphology, Gram reaction (test with $3 \% \mathrm{KOH}$ and staining), L-alanine aminopeptidase activity (Carlone et al. 1982), cell morphology, spore formation, the presence of oxidase and catalase, oxidative/fermentative metabolism of glucose, determination of motility, the presence of fluorescent pigment, production of levan and dihydrolase from arginine, nitrate reduction to nitrite, starch hydrolysis, and the utilization of glucose, lactose, trehalose, raffinose, sucrose, mannitol, and sorbitol.

\section{DNA-based identification}

For the isolation of genomic DNA from bacteria, a single colony of the tested isolate growing on King B medium was transferred to an Eppendorf tube $(2 \mathrm{ml})$ containing $0.5 \mathrm{ml}$ of sterile distilled water (MilliQ). To release DNA from bacterial cells, the resulting suspension was boiled in a water bath for $10 \mathrm{~min}$ and then cooled and centrifuged. To carry out the amplification reaction, $50 \mu \mathrm{l}$ of the reaction mixture was prepared with the following composition: 5.0 $\mu$ l DNA; 5.0 $\mu \mathrm{l}$ dNTP (0.2 mM, Fermentas, Life Science, Lithuania); $3.0 \mu$ l of primer fD1 $(10 \mathrm{nM}) ; 3.0 \mu \mathrm{lP} 2 \operatorname{primer}(10 \mathrm{nM})$ (Weisburg et al. 1991; Drancourt et al. 1997); $5.0 \mu \mathrm{l}$ buffer, $1 \mathrm{U}$ polymerase (DreamTaq, ThermoScientific,
Lithuania). The PCR was carried out in a thermocycler (T3000, Biometra, Germany) under the following conditions: initial denaturation $3 \mathrm{~min}$ at $94{ }^{\circ} \mathrm{C} ; 35$ cycles at $94{ }^{\circ} \mathrm{C}(1 \mathrm{~min}), 49^{\circ} \mathrm{C}(1 \mathrm{~min})$ and $72^{\circ} \mathrm{C}(1 \mathrm{~min}$ and $30 \mathrm{~s})$; and the final stage of extension $72{ }^{\circ} \mathrm{C}$ for 10 . The amplicon was separated by electrophoresis in a $1.5 \%$ agarose gel in $0.5 \times \mathrm{TBE}$ buffer. The gel was then stained in an ethidium bromide solution, and the obtained product was excised from the gel and purified using the DNA isolation kit (A\&A Biotechnology, Poland) according to the manufacturer's instructions. The purified product was sequenced by a commercial service (Genomed SA, Warsaw, Poland). The sequences obtained were compared with the EzTaxon program (http://www.ezbiocloud.net/eztaxon) and the blast-n algorithm with sequences of reference strains from the GenBank database (http://www.ncbi.nlm.nih.gov).

Pathogenicity assays

\section{Pear fruitlet test}

The immature pear fruitlet assays of Sobiczewski and Millikan (1985) were modified to assess the pathogenicity of the studied strains. Fruitlet slices of cv. Conference approx. $6-8 \mathrm{~mm}$ thick were immersed briefly in their water suspension at $1.0 \times 10^{8} \mathrm{CFU} \mathrm{ml}^{-1}$, laid out on moist filter paper in Petri plates and incubated for 7 days at $26^{\circ} \mathrm{C}$, observing the occurrence of possible disease symptoms.

\section{Hypersensitivity test on tobacco}

Suspensions of tested isolates in sterile distilled water $\left(10^{7} \mathrm{CFU} \mathrm{ml}^{-1}\right)$ obtained after washing out the bacteria from King B medium after $24 \mathrm{~h}$ of incubation were introduced into the mesophyll of the tobacco leaf cv. Samsun with a medical syringe. The reaction was observed after 18-24 h (Schaad et al. 2001).

\section{Test on apple blossoms}

The test was conducted in a greenhouse on one-year-old apple trees of the Idared cultivar at full blooming, planted in pots. Suspensions of the tested strains at $1.0 \times$ $10^{8} \mathrm{CFU} \mathrm{ml} \mathrm{ml}^{-1}$ were applied to the blossoms using the hand sprayer. After treatment, the trees were covered for $24 \mathrm{~h}$ with plastic bags to prevent the bacteria from drying out. Observations and evaluation of the occurrence of 
disease symptoms were carried out for a period of 7 days. For comparison, strain Ea659 was used.

\section{Pectolytic activity on potato tuber tissue and CVP medium}

Potato tubers were washed in tap water, surface sterilized in $70 \%$ ethanol and rinsed several times in sterile distilled water. On the surface of tuber slices with a thickness of approx. $10 \mathrm{~mm}$ placed on a wet filter paper in Petri plates, the bacterial suspensions of tested strains

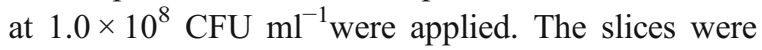
incubated for 7 days at $26^{\circ} \mathrm{C}$, and disease changes were observed (Mikiciński et al. 2016). For comparison, strain 853 (Pectobacterium carotovorum subsp. carotovorum) deposited in the collection of bacterial isolates of the Department of Phytopathology RIH, causing strong softening and decay of potato tissues $24 \mathrm{~h}$ after application, was used.

The CVP medium was prepared according to the methodology described by Schaad et al. (2001). The tested bacteria were seeded on medium surface and incubated at $27{ }^{\circ} \mathrm{C}$ for $2-4$ days. The appearance of characteristic pits around colonies indicated positive results.

Commercial products and preparation of working liquids

The following commercial products were used for comparison: Miedzian 50 WP (50\% copper oxychloride), registered in Poland for control of fire blight, and BlightBan A506 (A506 lyophilisate). Miedzian 50 WP was tested at concentrations of $0.15 \%$ and $0.3 \%$, which corresponded to the doses recommended for the use in practice, i.e., $1.5 \mathrm{~kg}$ and $3.0 \mathrm{~kg}$ per hectare, respectively. Its working liquids were prepared by mixing the preparation with distilled water. The working liquid of BlightBan A506 was prepared as recommended by the manufacturer: $10 \mathrm{~g}$ of lyophilisate was dissolved in $1000 \mathrm{ml}$ of sterile distilled water $\left(10^{7} \mathrm{CFU} \mathrm{ml}^{-1}\right)$. Both products were applied on blossoms and/or on terminal shoots using a hand sprayer.

The biotic relation between tested isolates and E. amylovora

The tests were carried out on the following media: NAS, King B, LB (tryptone $1 \%, \mathrm{NaCl} 1 \%$, yeast extract $0.5 \%$, agar $2 \%$ ), R2A (yeast extract $0.05 \%$, peptone $0.05 \%$, casein hydrolysate $0.05 \%$, starch $0.05 \%$, glucose $0.05 \%, \mathrm{~K}_{2} \mathrm{HPO}_{4} 0.03 \%, \mathrm{MgSO}_{4} \times \mathrm{H}_{2} \mathrm{O} 0.03 \%, \mathrm{NaCl}$ $0.03 \%$, agar $1.5 \%$ ) (Reasoner and Geldreich 1985), NAG (nutrient agar $2.3 \%$, glycerol $16 \mathrm{ml}$ ) and 925 (glucose $0.5 \%, \mathrm{~K}_{2} \mathrm{HPO}_{4} 0.3 \%, \mathrm{NaH}_{2} \mathrm{PO}_{4} 0.1 \% \mathrm{NH}_{4} \mathrm{Cl}$ $0.1 \%, \mathrm{MgSO}_{4} \times \mathrm{H}_{2} \mathrm{O} 0.03 \%$, agar $1.5 \%$ ) (Kado 1979). Bacteria were spot seeded on the appropriate medium in the centre of Petri plates. After 3 days of incubation at $26^{\circ} \mathrm{C}$, the bacteria were killed in chloroform vapor, and then the surface of the media was flooded with $4 \mathrm{ml}$ of cooled soft agar with the addition of $100 \mu$ of Ea659 suspension $\left(10^{8} \mathrm{CFU} \mathrm{ml}{ }^{-1}\right)$. Inhibition zones of pathogen growth were measured after 24 and $48 \mathrm{~h}$ incubation at $26^{\circ} \mathrm{C}$. An exception was the medium 925 on which observation was performed also after $72 \mathrm{~h}$. Each strain was tested in 6 replicates.

Efficacy of fire blight control by tested isolates on apple blossoms and terminal shoots

\section{Experiments on blossoms}

The study was carried out in a greenhouse on one-yearold apple trees cv. Idared planted in pots and on detached apple branches of cultivars Idared, Linda and Jonagored. The branches were cut from trees growing in commercial orchards not protected with copper products. Their base was immersed in tap water in glass jars, which were then placed in a greenhouse on a table with a special frame covered with foil, forming a kind of tent. By the continuous wetting of the surface of the table lined with an infiltration mat, the humidity was maintained at 90 to $100 \%$. The temperature in the greenhouse was $20-24{ }^{\circ} \mathrm{C}$.

Protective sprayings of trees and detached branches with suspensions of the tested strains, bio-preparation BlightBan A506 and copper product Miedzian 50 WP were performed once at full bloom. After $24 \mathrm{~h}$, they were inoculated by spraying with $E$. amylovora suspension of strain Ea659 at $1.0 \times 10^{7} \mathrm{CFU} \mathrm{ml}^{-1}$. The control combination constituted spraying with sterile distilled water at the same time as protective sprayings and after $24 \mathrm{~h}$ inoculations were made. Next, all trees were covered with plastic bags for $24 \mathrm{~h}$.

Each combination, on both trees and branches, consisted of 160 flowers (four replicates of 40 flowers on 5-10 trees or 4-10 branches). The degree of blossom infection was assessed using the Pusey (1999) 5-point 
scale with slight modification: 0 - no visible symptoms of the disease, 1 - symptoms on the flower and/or flower bed, 2 - symptoms including the whole ovary, 3 - symptoms reaching at least half of the flower stalk, and 4 symptoms covering the whole flower together with the flower stalk. The assessment was carried out from 5 to 9 days after inoculation. The effectiveness of each bacterial strain and commercial products was determined on the last day of evaluation.

\section{Experiments on terminal shoots of apple trees}

The study was carried out in a greenhouse on oneyear-old apple trees of susceptible to fire blight cultivar Gala Must and M.26 apple rootstock, planted in pots. The tips of the $30-40 \mathrm{~cm}$ actively growing shoots were cut with sterile scissors under the first developed leaf. The suspension of tested strains and commercial products was immediately applied to the wound surface using a hand sprayer, after which the shoots were covered with plastic bags. Inoculations by spraying with $E$. amylovora suspension of strain Ea659 at $1.0 \times 10^{7} \mathrm{CFU} \mathrm{ml}{ }^{-1}$ were made after $24 \mathrm{~h}$. The control combination consisted of trees whose wounded shoots were sprayed with sterile distilled water. After inoculation, all shoots were covered with bags for $24 \mathrm{~h}$. Each combination consisted of 20 trees (four replicates with five trees, 10 shoots per replicate). At each assessment date (7, 10, and 17 days after inoculation - experiment 1 ; or 12,18 , and $26-$ experiment 2), the percentage of shoot infestation was determined by comparing the length of the diseased part of the shoot to its total length (Sobiczewski et al. 2015).

\section{Statistical analyses}

The homoscedasticity assumption of the data was evaluated by Levene's test. The results were elaborated using ANOVA on non-transformed data. For comparison of means, the Newman-Keuls test was used. In case of analysis of fire blight severity on M26 and Gala Must/M.26 shoots nonparametric Kruskal-Walils ANOVA was used and the treatments were compared with Dunn test. All calculations were done using STATISTICA v.13 software package (Dell Inc. 2016) at $p=0.05$.

\section{Results}

Identification of tested bacteria

Identification of all tested isolates showed that they were Gram-negative motile rods that did not have the ability to form spores but produced catalase and had the ability to use glucose and mannitol as a carbon source (Table 1). Isolates B90, $43 \mathrm{M}, 48 \mathrm{M}$ and $141 \mathrm{M}$ metabolized glucose under both aerobic and anaerobic conditions. The remaining isolates showed only oxidative metabolism (Table 1). Isolates $3 \mathrm{M}$ and $35 \mathrm{M}$ produced levan from sucrose and on the King B medium - a fluorescent pigment visible under UV light. The formation of this pigment was also found by isolates L16 and $59 \mathrm{M}$. Isolates B90, L16, $35 \mathrm{M}$, $43 \mathrm{M}, 48 \mathrm{M}, 49 \mathrm{M}$, and $141 \mathrm{M}$ did not produce oxidase, and L16, $3 \mathrm{M}$ and $141 \mathrm{M}$ hydrolysed starch. Only isolates B90, $3 \mathrm{M}, 43 \mathrm{M}, 48 \mathrm{M}$ and $141 \mathrm{M}$ reduced nitrate to nitrite, and only isolates $3 \mathrm{M}, 43 \mathrm{M}$ and $59 \mathrm{M}$ produced arginine dihydrolase. In addition to the abovementioned carbohydrates, isolate $43 \mathrm{M}$ showed this feature to all other four sugars and sorbitol, and isolate $3 \mathrm{M}$ only for trehalose, raffinose and sucrose. Isolates B90 and $48 \mathrm{M}$ were able to use trehalose and sucrose, $35 \mathrm{M}$ - sorbitol and sucrose, $141 \mathrm{M}$ - trehalose and sorbitol, $59 \mathrm{M}$ and L16 trehalose (weak reaction) (Table 1).

The results of $16 \mathrm{~S}$ rRNA gene fragment sequence analysis allowed the identification of isolates L16 as Pseudomonas vancouverensis, $3 \mathrm{M}$ - Pseudomonas chlororaphis subsp. aureofaciens, $35 \mathrm{M}$ - Pseudomonas congelans, $43 \mathrm{M}$ - Enterobacter ludwigii, $59 \mathrm{M}$ - Pseudomonas protegens, $141 \mathrm{M}$ - Erwinia billingiae, and B90 and $48 \mathrm{M}-$ Pantoea agglomerans, (Table 2). The identification carried out authorized the change in the status of the tested bacteria from isolate to strain. Analyses for three isolates showed $100 \%$ similarity to the reference strains, four over $99 \%$ and one over $98 \%$ (Table 2). In almost all cases, the result of DNA analysis confirmed the result of the identification of tested isolates on the basis of phenotypic characteristics with regard to their belonging to the genus (Table 2).

The tobacco hypersensitivity test showed that only the $35 \mathrm{M}$ strain caused characteristic necrosis between leaf veins. This strain was also the cause of very small brown spots on the bottom of apple blossoms and on slices of pear fruitlets. None of the tested strains caused soft rot decay of potato tubers and did not create characteristic pits around colonies on CVP medium, which indicates a lack of pectinolytic activity. 


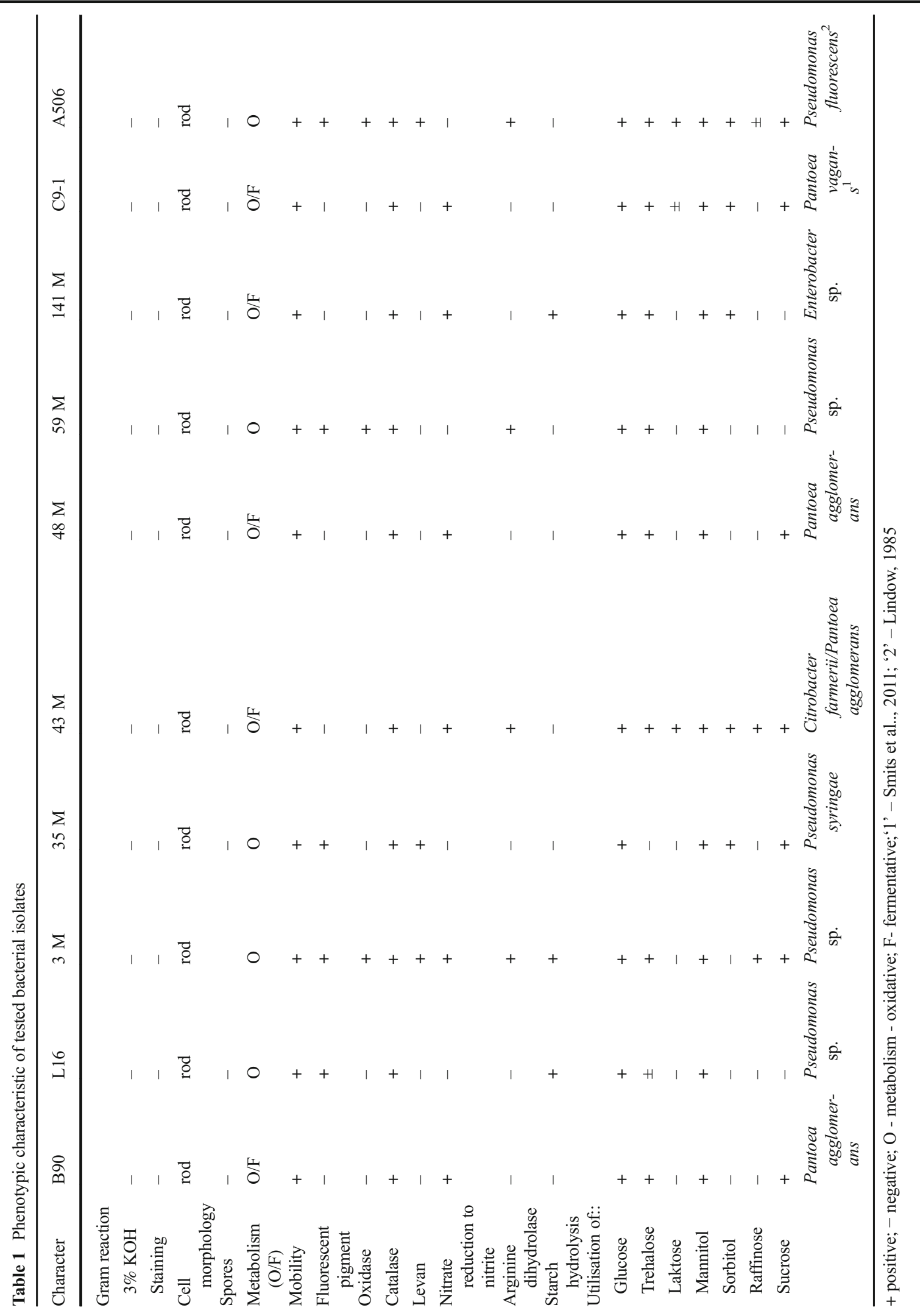


Table 2 Identification of isolates based on 16S rDNA sequence

\begin{tabular}{|c|c|c|c|}
\hline \multirow[t]{2}{*}{ Isolate } & \multicolumn{3}{|l|}{ 16S rDNA } \\
\hline & Species/ Geneus & $\% \mathrm{P}^{*}$ & $\begin{array}{l}16 \mathrm{~S} \text { sequences access number } \\
\text { from the GenBank database }\end{array}$ \\
\hline B90 & Pantoea agglomerans ATCC $27155^{\mathrm{T}}$ & 99,82 & AJ233423 \\
\hline L16 & Pseudomonas vancouverensis ATCC $700688^{\mathrm{T}}$ & 98,61 & AJ011507 \\
\hline $3 \mathrm{M}$ & Pseudomonas chlororaphis subsp. aureofaciens NBRC $3521^{\mathrm{T}}$ & 99,69 & AY509898 \\
\hline $35 \mathrm{M}$ & Pseudomonas congelans DSM $14939^{\mathrm{T}}$ & 100 & AJ492828 \\
\hline $43 \mathrm{M}$ & Enterobacter ludwigii $\mathrm{EN}-119^{\mathrm{T}}$ & 100 & AJ853891 \\
\hline $48 \mathrm{M}$ & Pantoea agglomerans DSM $3493^{\mathrm{T}}$ & 100 & AJ233423 \\
\hline $59 \mathrm{M}$ & Pseudomonas protegens $\mathrm{CHA} 0^{\mathrm{T}}$ & 99,86 & AJ278812 \\
\hline $141 \mathrm{M}$ & Erwinia billingiae LMG $2613^{\mathrm{T}}$ & 99,85 & JN175337 \\
\hline
\end{tabular}

$* \% \mathrm{P}$ - percent of similarity to the sequences in the database

Antagonistic activity

A study on the biotic relationships between the tested strains and E. amylovora showed that B90, $43 \mathrm{M}, 48 \mathrm{M}$ and $141 \mathrm{M}$ did not show the ability to inhibit the growth of the pathogen on any of the six media used (Table 3). Strain L16 did not inhibit the growth of this bacterium on LB and R2A media. Only strains $3 \mathrm{M}, 35 \mathrm{M}$ and $59 \mathrm{M}$ formed inhibition zones with a width of 1.0 to $15.5 \mathrm{~mm}$ on all media except 925 , on which all strains stimulated the growth of the pathogen, clearly visible after $72 \mathrm{~h}$ (Fig. 1). It is worth noting that E. amylovora did not grow on this medium without co-cultivation with the tested bacteria The C9-1 and A506 reference strains formed inhibition zones on R2A and NAG media, and the A506 strain did so on King B. In most cases, E. amylovora inhibition zones observed after $24 \mathrm{~h}$ of coculture with potential antagonists decreased or disappeared completely after the next $24 \mathrm{~h}$.

\section{Efficacy}

The assessments of the efficacy of the tested bacteria and products showed their protective ability against fire blight, which was indicated by a significantly lower degree of apple blossoms and terminal shoot

Table 3 Inhibition zones of E. amylovora growth ( $\mathrm{mm}$ ) caused by antagonistic bacteria on microbiological media

\begin{tabular}{|c|c|c|c|c|c|c|c|c|c|c|c|}
\hline \multirow[t]{3}{*}{ Bacterial strain } & \multicolumn{11}{|c|}{ Medium } \\
\hline & \multicolumn{2}{|l|}{ NAS } & \multicolumn{2}{|c|}{ King B } & \multicolumn{2}{|l|}{ LB } & \multicolumn{2}{|l|}{$\mathrm{R} 2 \mathrm{~A}$} & \multicolumn{2}{|l|}{ NAG } & \multirow{2}{*}{$\begin{array}{l}925 \\
72 \mathrm{~h}\end{array}$} \\
\hline & $24 \mathrm{~h}^{*}$ & $48 \mathrm{~h}$ & $24 \mathrm{~h}$ & $48 \mathrm{~h}$ & $24 \mathrm{~h}$ & $48 \mathrm{~h}$ & $24 \mathrm{~h}$ & $48 \mathrm{~h}$ & $24 \mathrm{~h}$ & $48 \mathrm{~h}$ & \\
\hline B90 & $0.0 \mathrm{a}$ & $0.0 \mathrm{a}$ & $0.0 \mathrm{a}$ & $0.0 \mathrm{a}$ & $0.0 \mathrm{a}$ & $0.0 \mathrm{a}$ & $0.0 \mathrm{a}$ & $0.0 \mathrm{a}$ & $0.0 \mathrm{a}$ & $0.0 \mathrm{a}$ & + \\
\hline L16 & $16.5 \mathrm{e}$ & $10.5 \mathrm{c}$ & $7.5 \mathrm{~b}$ & $5.0 \mathrm{~b}$ & $0.0 \mathrm{a}$ & $0.0 \mathrm{a}$ & $0.0 \mathrm{a}$ & $0.0 \mathrm{a}$ & $5.0 \mathrm{e}$ & $4.8 \mathrm{e}$ & + \\
\hline $3 \mathrm{M}$ & $4.0 \mathrm{~d}$ & $4.0 \mathrm{~b}$ & $13.5 \mathrm{e}$ & $6.0 \mathrm{c}$ & $5.5 \mathrm{c}$ & $5.5 \mathrm{c}$ & $1.5 \mathrm{c}$ & $1.5 \mathrm{c}$ & $7.0 \mathrm{~g}$ & $6.6 \mathrm{~g}$ & + \\
\hline $35 \mathrm{M}$ & $1.0 \mathrm{~b}$ & $0.0 \mathrm{a}$ & $9.5 \mathrm{c}$ & $0.0 \mathrm{a}$ & $1.0 \mathrm{~b}$ & $1.0 \mathrm{~b}$ & $2.0 \mathrm{~d}$ & $1.5 \mathrm{c}$ & $3.0 \mathrm{~d}$ & $3.0 \mathrm{~d}$ & + \\
\hline $43 \mathrm{M}$ & $0.0 \mathrm{a}$ & $0.0 \mathrm{a}$ & $0.0 \mathrm{a}$ & $0.0 \mathrm{a}$ & $0.0 \mathrm{a}$ & $0.0 \mathrm{a}$ & $0.0 \mathrm{a}$ & $0.0 \mathrm{a}$ & $0.0 \mathrm{a}$ & $0.0 \mathrm{a}$ & + \\
\hline $48 \mathrm{M}$ & $0.0 \mathrm{a}$ & $0.0 \mathrm{a}$ & $0.0 \mathrm{a}$ & $0.0 \mathrm{a}$ & $0.0 \mathrm{a}$ & $0.0 \mathrm{a}$ & $0.0 \mathrm{a}$ & $0.0 \mathrm{a}$ & $0.0 \mathrm{a}$ & $0.0 \mathrm{a}$ & + \\
\hline $59 \mathrm{M}$ & $3.5 \mathrm{c}$ & $0.0 \mathrm{a}$ & $15.5 \mathrm{f}$ & $11.5 \mathrm{~d}$ & $12.5 \mathrm{~d}$ & $11.0 \mathrm{~d}$ & $0.7 \mathrm{~b}$ & $0.0 \mathrm{a}$ & $1.5 \mathrm{~b}$ & $1.0 \mathrm{~b}$ & + \\
\hline $141 \mathrm{M}$ & $0.0 \mathrm{a}$ & $0.0 \mathrm{a}$ & $0.0 \mathrm{a}$ & $0.0 \mathrm{a}$ & $0.0 \mathrm{a}$ & $0.0 \mathrm{a}$ & $0.0 \mathrm{a}$ & $0.0 \mathrm{a}$ & $0.0 \mathrm{a}$ & $0.0 \mathrm{a}$ & + \\
\hline A506 & $0.0 \mathrm{a}$ & $0.0 \mathrm{a}$ & $11.5 \mathrm{~d}$ & $0.0 \mathrm{a}$ & $0.0 \mathrm{a}$ & $0.0 \mathrm{a}$ & $1.3 \mathrm{c}$ & $1.1 \mathrm{~b}$ & $6.0 \mathrm{f}$ & $6.0 \mathrm{f}$ & + \\
\hline C9-1 & $0.0 \mathrm{a}$ & $0.0 \mathrm{a}$ & $0.0 \mathrm{a}$ & $0.0 \mathrm{a}$ & $0.0 \mathrm{a}$ & $0.0 \mathrm{a}$ & $1.9 \mathrm{~d}$ & $1.7 \mathrm{c}$ & $2.5 \mathrm{c}$ & $2.0 \mathrm{c}$ & + \\
\hline
\end{tabular}

*Time of measurement; statistical analysis was performed separately for each term; means with the same letters are not significantly different at $P<0.05$ according to Newman-Keuls test 

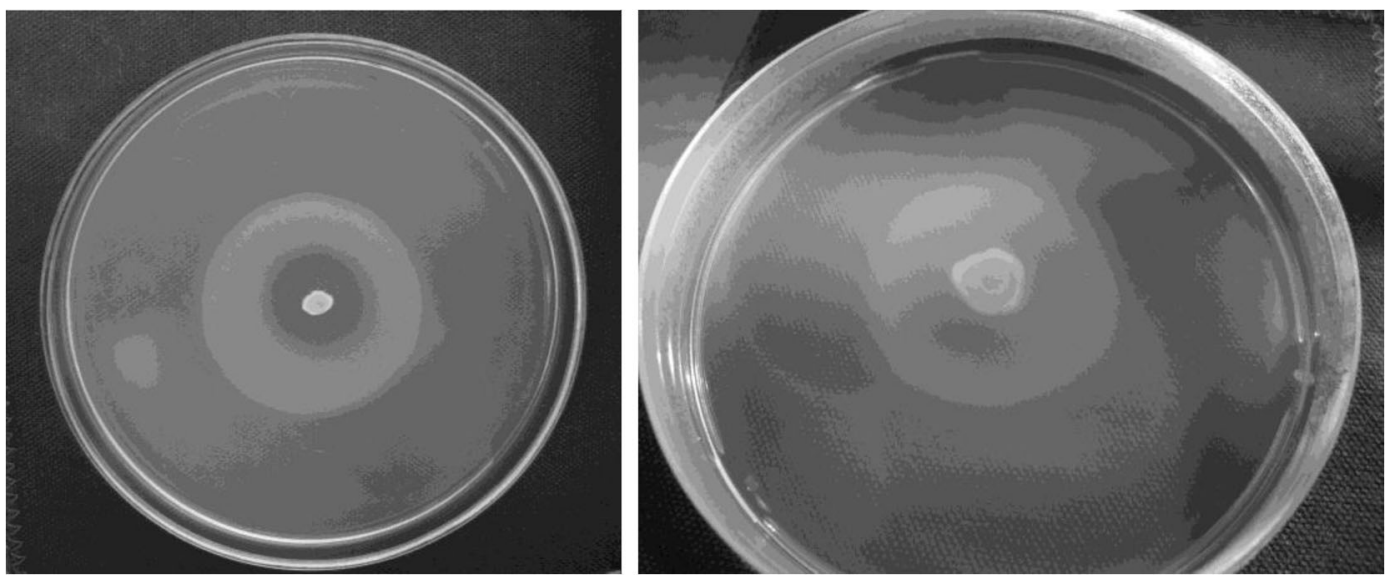

Fig. 1 The growth stimulation zone of Erwinia amylovora on 925 medium around bacterial strains: from left L16, 141 M (3 days after incubation)

infection compared to the control. In experiments 1 and 2 performed on young apple trees, no significant differences in the degree of blossom infection treated with both the tested and the reference strains (A506 and C9-1) or with Blossom Blight A506 were found (Table 4). Evaluation carried out 9 days after inoculation showed the highest efficacy $(70 \%$ or more) of strains $35 \mathrm{M}, 48 \mathrm{M}$ and C9-1. Strains $141 \mathrm{M}, 59 \mathrm{M}, \mathrm{A} 506$, and C9-1 showed an efficiency ranging from 84 to $93 \%$ (Table 4 ).

Table 4 Severity of fire blight on apple blossoms after protective treatment with bacterial suspension of studied strains or commercial formulations

\begin{tabular}{|c|c|c|c|c|}
\hline \multirow[t]{3}{*}{ Bacterial strain/ product } & \multicolumn{4}{|c|}{ Days after inoculation } \\
\hline & \multicolumn{2}{|l|}{$\begin{array}{l}\text { Experiment } 1 \\
\text { Idared/ M.26 }\end{array}$} & \multicolumn{2}{|l|}{$\begin{array}{l}\text { Experiment } 2 \\
\text { Idared/ M.9 }\end{array}$} \\
\hline & 6 & 9 & 6 & 8 \\
\hline Control & $1.53 \pm 0.34 b^{1}$ & $2.57 \pm 031 b$ & $2.59 \pm 0.34 b$ & $3.33 \pm 0.19 b$ \\
\hline B90 & $0.23 \pm 0.17 \mathrm{a}$ & $0.94 \pm 0.39 \mathrm{a}(63)$ & $\mathrm{nt}$ & $\mathrm{nt}$ \\
\hline L16 & $0.27 \pm 0.11 \mathrm{a}$ & $1.04 \pm 0.37 \mathrm{a}(60)$ & $\mathrm{nt}$ & $\mathrm{nt}$ \\
\hline $3 \mathrm{M}$ & $0.28 \pm 0.14 \mathrm{a}$ & $0.96 \pm 0.27 \mathrm{a}(63)$ & $\mathrm{nt}$ & $\mathrm{nt}$ \\
\hline $35 \mathrm{M}$ & $0.21 \pm 0.12 \mathrm{a}$ & $0.76 \pm 0.16 \mathrm{a}(70)$ & $\mathrm{nt}$ & $\mathrm{nt}$ \\
\hline $43 \mathrm{M}$ & $0.48 \pm 0.19 a$ & $1.16 \pm 0.30 \mathrm{a}(55)$ & $\mathrm{nt}$ & $\mathrm{nt}$ \\
\hline $48 \mathrm{M}$ & $0.22 \pm 0.12 \mathrm{a}$ & $0.71 \pm 0.26 \mathrm{a}(72)$ & $\mathrm{nt}$ & $\mathrm{nt}$ \\
\hline $59 \mathrm{M}$ & $\mathrm{nt}$ & $\mathrm{nt}$ & $0.14 \pm 0.08 \mathrm{a}$ & $0.30 \pm 0.12 \mathrm{a}(90)$ \\
\hline $141 \mathrm{M}$ & $\mathrm{nt}$ & $\mathrm{nt}$ & $0.16 \pm 0.12 \mathrm{a}$ & $0.25 \pm 0.19 \mathrm{a}(93)$ \\
\hline A 506 & $0.41 \pm 0.19 \mathrm{a}$ & $0.83 \pm 0.13 \mathrm{a}(68)$ & $0.22 \pm 0.16 \mathrm{a}$ & $0.47 \pm 0.29 \mathrm{a}(86)$ \\
\hline C9-1 & $0.16 \pm 0.05 a$ & $0.70 \pm 0.35 \mathrm{a}(73)$ & $0.26 \pm 0.11 \mathrm{a}$ & $0.53 \pm 0.22 \mathrm{a}(84)$ \\
\hline BB A506 & $0.28 \pm 0.17 \mathrm{a}$ & $1.02 \pm 0.17 \mathrm{a}(60)$ & $\mathrm{nt}$ & $\mathrm{nt}$ \\
\hline M $0.15 \%$ & $\mathrm{nt}$ & $\mathrm{nt}$ & $\mathrm{nt}$ & $\mathrm{nt}$ \\
\hline M $0.3 \% 3$ & $\mathrm{nt}$ & $\mathrm{nt}$ & $\mathrm{nt}$ & $\mathrm{nt}$ \\
\hline
\end{tabular}

Both experiments were carried out on potted apple trees, BB A506: BlightBan A506; M - Miedzian 50 WP; concentrations of bacterial suspensions of all strains $10^{8} \mathrm{CFU} \mathrm{ml}^{-1}$; ' 1 ' - infection rating scale: 0 - no symptoms, 4 - total necrosis flower; nt: not tested; statistical analysis was performed separately for each term; means with the same letters are not significantly different at $P<0.05$ according to Newman-Keuls test (means $\pm \mathrm{SE}$ ), data in brackets show the efficacy in \% (degree of blossom infection treated with suspensions of the bacteria or commercial product in relation to control); nt: not tested 
Also in experiments performed on detached apple branches, a significantly lower degree of apple blossom infection after protective use of the tested bacteria and products in comparison to the control was found (Table 5). In experiment 1 , observations made 6 days after inoculation showed no significant differences in the degree of infection of blossoms protectively treated with bacteria and the copper product at a concentration of $0.15 \%$. Observations made 3 days later showed a similar tendency, although the efficacy of the tested strains decreased. The highest efficiency showed strains C9-1 (77\%) and $48 \mathrm{M}(72 \%)$, and the lowest - $3 \mathrm{M}$ (62\%). Of the tested products, the lowest efficacy was with the product BlightBan A506 (32\%) (Table 5). The results of observations made 6 days after inoculation in experiment 2 showed the lowest degree of blossom infection after application of strain L16. However, the assessment after 9 days of inoculation did not reveal any significant differences in the degree of infection of blossoms treated with all bacterial strains. It should be emphasized that all strains proved to be more effective than the copper product at both doses. Strain L16 appeared to be the most effective one.. Also the evaluation made 7 days after inoculation in experiment 3 showed that all the tested bacteria better protected the blossoms than copper product at a concentration of $0.15 \%$. On the other hand, observations made 2 days later showed a similar degree of blossom infection after the protective use of all bacteria and copper product at both concentrations. The highest efficiency was found with strain $48 \mathrm{M}$ and the copper product at a concentration of $0.3 \%$.

Observations carried out 7,10 and 17 days after inoculation with M.26 rootstock showed significantly lower infection of shoots protected with almost all tested bacteria compared to the control (Table 6). In all terms of evaluation, the highest efficacy in reducing the severity of the disease showed strains $35 \mathrm{M}$ and $43 \mathrm{M}$ whereas the poorest protective abilities were observed after using the L16 strain and BlightBan A 506.. Experiment on Gala Must cv. revealed very high protective abilities of all tested bacteria on the shoots, as the effectiveness in all three assessment terms was $100 \%$ (Table 6).

Table 5 Severity of fire blight on apple blossoms after protective treatment with bacterial suspension of studied strains or commercial formulations

\begin{tabular}{|c|c|c|c|c|c|c|}
\hline \multirow[t]{3}{*}{ Bacterial strain/ product } & \multicolumn{6}{|c|}{ Days after inoculation } \\
\hline & \multicolumn{2}{|l|}{$\begin{array}{l}\text { Experiment } 1 \\
\text { Idared/ M.26 }\end{array}$} & \multicolumn{2}{|c|}{$\begin{array}{l}\text { Experiment } 2 \\
\text { Linda/ Antonovka }\end{array}$} & \multicolumn{2}{|c|}{$\begin{array}{l}\text { Experiment } 3 \\
\text { Jonagored/M.26 }\end{array}$} \\
\hline & 6 & 9 & 6 & 9 & 7 & 9 \\
\hline Control & $0.44 \pm 0.19 c^{1}$ & $1.08 \pm 0.28 \mathrm{c}$ & $0.88 \pm 0.16 \mathrm{~d}$ & $2.01 \pm 0.27 \mathrm{~d}$ & $1.32 \pm 0.20 \mathrm{c}$ & $1.45 \pm 0.39 b$ \\
\hline B90 & $0.07 \pm 0.04 \mathrm{a}$ & $0.32 \pm 0.12 \mathrm{ab}(70)$ & $0.08 \pm 0.07 \mathrm{ab}$ & $0.42 \pm 0.31 \mathrm{a}(79)$ & $\mathrm{nt}$ & nt \\
\hline L16 & $0.12 \pm 0.05 \mathrm{a}$ & $0.35 \pm 0.10 \mathrm{ab}(68)$ & $0.06 \pm 0.02 \mathrm{a}$ & $0.23 \pm 0.17 \mathrm{a}(89)$ & $\mathrm{nt}$ & $\mathrm{nt}$ \\
\hline $3 \mathrm{M}$ & $0.13 \pm 0.06 a$ & $0.41 \pm 0.24 \mathrm{ab}(62)$ & $0.17 \pm 0.04 \mathrm{ab}$ & $0.33 \pm 0.16 \mathrm{a}(84)$ & nt & $\mathrm{nt}$ \\
\hline $35 \mathrm{M}$ & $\mathrm{nt}$ & $\mathrm{nt}$ & $0.14 \pm 0.09 \mathrm{ab}$ & $0.43 \pm 0.15 \mathrm{a}(79)$ & $\mathrm{nt}$ & $\mathrm{nt}$ \\
\hline $43 \mathrm{M}$ & $0.09 \pm 0.07 \mathrm{a}$ & $0.31 \pm 0.06 \mathrm{ab}(71)$ & $0.11 \pm 0.04 \mathrm{ab}$ & $0.28 \pm 0.10 \mathrm{a}(86)$ & $\mathrm{nt}$ & $\mathrm{nt}$ \\
\hline $48 \mathrm{M}$ & $0.04 \pm 0.02 \mathrm{a}$ & $0.30 \pm 0.27 \mathrm{ab}(72)$ & $0.12 \pm 0.06 \mathrm{ab}$ & $0.38 \pm 0.13 \mathrm{a}(81)$ & $0.22 \pm 0.08 \mathrm{a}$ & $0.29 \pm 0.19 \mathrm{a}(80)$ \\
\hline $59 \mathrm{M}$ & $\mathrm{nt}$ & $\mathrm{nt}$ & $\mathrm{nt}$ & $\mathrm{nt}$ & $0.22 \pm 0.08 \mathrm{a}$ & $0.44 \pm 0.20 \mathrm{a}(70)$ \\
\hline $141 \mathrm{M}$ & $\mathrm{nt}$ & $\mathrm{nt}$ & $\mathrm{nt}$ & $\mathrm{nt}$ & $0.10 \pm 0.12 \mathrm{a}$ & $0.35 \pm 0.14 \mathrm{a}(76)$ \\
\hline A 506 & $0.07 \pm 0.06 \mathrm{a}$ & $0.39 \pm 0.13 \mathrm{ab}(64)$ & $0.30 \pm 0.16 b c$ & $0.49 \pm 0.31 \mathrm{a}(76)$ & $\mathrm{nt}$ & $\mathrm{nt}$ \\
\hline C9-1 & $0.11 \pm 0.06 \mathrm{a}$ & $0.25 \pm 0.12 \mathrm{a}(77)$ & $0.18 \pm 0.09 \mathrm{ab}$ & $0.35 \pm 0.11 \mathrm{a}(83)$ & $0.13 \pm 0.12 \mathrm{a}$ & $0.47 \pm 0.26 \mathrm{a}(68)$ \\
\hline BB A506 & $0.23 \pm 0.12 b$ & $0.73 \pm 0.35 b(32)$ & $\mathrm{nt}$ & $\mathrm{nt}$ & nt & $\mathrm{nt}$ \\
\hline M $0.15 \%$ & $0.09 \pm 0.08 \mathrm{a}$ & $0.43 \pm 0.22 \mathrm{ab}(60)$ & $0.43 \pm 0.14 c$ & $1.04 \pm 0.28 \mathrm{c}(48)$ & $0.55 \pm 0.33 b$ & $0.65 \pm 0.13 \mathrm{a}(55)$ \\
\hline M $0.3 \% 3$ & $0.15 \pm 0.07 b$ & $0.48 \pm 0.19 \mathrm{ab}(56)$ & $0.43 \pm 0.09)$ & $0.69 \pm 0.21 b(66)$ & $0.26 \pm 0.08 \mathrm{a}$ & $0.27 \pm 0.19 \mathrm{a}(81)$ \\
\hline
\end{tabular}

Three independent experiments carried out on detached apple branches, BB A506: BlightBan A506; M - Miedzian 50 WP; concentrations of bacterial suspensions of all strains $10^{8} \mathrm{CFU} \mathrm{ml}{ }^{-1}$; ' 1 ' - infection rating scale: 0 - no symptoms, 4 - total necrosis flower; nt: not tested; statistical analysis was performed separately for each term; means with the same letters are not significantly different at $p=0.05$ according to Newman-Keuls test (means $\pm \mathrm{SE}$ ), data in brackets show the efficacy in \% (degree of blossom infection treated with suspensions of the bacteria or commercial product in relation to control); nt: not tested 
Table 6 Severity of fire blight on apple terminal shoots after protective treatment with bacterial suspension of studied isolates or commercial formulation

\begin{tabular}{|c|c|c|c|c|c|c|}
\hline \multirow[t]{3}{*}{ Bacterial strain/ product } & \multicolumn{6}{|c|}{ Days after inoculation } \\
\hline & \multicolumn{3}{|c|}{ Rootstock M.26* } & \multicolumn{3}{|c|}{ Gala Must/M.26* } \\
\hline & 7 & 10 & 17 & 12 & 18 & 26 \\
\hline Control & $6.5 \pm 0.67 \mathrm{a}^{1}$ & $21.0 \pm 5.22 \mathrm{a}$ & $37.6 \pm 3.34 \mathrm{a}$ & $33.8 \pm 12.95 \mathrm{a}$ & $47.5 \pm 21.46 \mathrm{a}$ & $50.4 \pm 24.47 \mathrm{a}$ \\
\hline В 90 & $2.3 \pm 1.38 \mathrm{ab}$ & $3.6 \pm 1.48 \mathrm{~b}$ & $11.3 \pm 5.16 \mathrm{bcd}(70)$ & $\mathrm{nt}$ & $\mathrm{nt}$ & $\mathrm{nt}$ \\
\hline L16 & $1.6 \pm 0.63 b$ & $6.8 \pm 1.73 \mathrm{ab}$ & $26.1 \pm 9.00 \mathrm{ab}(31)$ & $\mathrm{nt}$ & $\mathrm{nt}$ & $\mathrm{nt}$ \\
\hline $3 \mathrm{M}$ & $1.1 \pm 1.10 \mathrm{~b}$ & $2.6 \pm 1.87 \mathrm{~b}$ & $12.3 \pm 7.56 \mathrm{abc}(67)$ & $\mathrm{nt}$ & $\mathrm{nt}$ & $\mathrm{nt}$ \\
\hline $35 \mathrm{M}$ & $0.0 \pm 0.00 \mathrm{c}$ & $0.0 \pm 0.00 \mathrm{c}$ & $1.4 \pm 1.28 \mathrm{e}(96)$ & $\mathrm{nt}$ & $\mathrm{nt}$ & $\mathrm{nt}$ \\
\hline $43 \mathrm{M}$ & $0.0 \pm 0.00 \mathrm{c}$ & $0.0 \pm 0.00 \mathrm{c}$ & $2.8 \pm 2.68 \mathrm{de}(93)$ & $\mathrm{nt}$ & $\mathrm{nt}$ & $\mathrm{nt}$ \\
\hline $48 \mathrm{M}$ & $0.9 \pm 0.85 b$ & $1.6 \pm 1.53 b c$ & $3.3 \pm 3.18 \mathrm{cde}(92)$ & $0.0 \pm 0.00 \mathrm{~b}$ & $0.0 \pm 0.00 \mathrm{~b}$ & $0.0 \pm 0.00 \mathrm{~b}(100)$ \\
\hline $59 \mathrm{M}$ & $\mathrm{nt}$ & $\mathrm{nt}$ & $\mathrm{nt}$ & $0.0 \pm 0.00 \mathrm{~b}$ & $0.0 \pm 0.00 \mathrm{~b}$ & $0.0 \pm 0.00 \mathrm{~b}(100)$ \\
\hline $141 \mathrm{M}$ & $\mathrm{nt}$ & $\mathrm{nt}$ & $\mathrm{nt}$ & $0.0 \pm 0.00 \mathrm{~b}$ & $0.0 \pm 0.00 \mathrm{~b}$ & $0.0 \pm 0.00 \mathrm{~b}(100)$ \\
\hline A 506 & $\mathrm{nt}$ & $\mathrm{nt}$ & $\mathrm{nt}$ & $0.0 \pm 0.00 \mathrm{~b}$ & $0.0 \pm 0.00 \mathrm{~b}$ & $0.0 \pm 0.00 \mathrm{~b}(100)$ \\
\hline C9-1 & $\mathrm{nt}$ & $\mathrm{nt}$ & $\mathrm{nt}$ & $0.0 \pm 0.00 \mathrm{~b}$ & $0.0 \pm 0.00 \mathrm{~b}$ & $0.0 \pm 0.00 \mathrm{~b}(100)$ \\
\hline BB A506 & $6.0 \pm 0.66 \mathrm{a}$ & $9.1 \pm 1.27 \mathrm{ab}$ & $16.8 \pm 1.50 \mathrm{ab}(55)$ & $\mathrm{nt}$ & $\mathrm{nt}$ & $\mathrm{nt}$ \\
\hline
\end{tabular}

The experiments were carried out on apple trees in a greenhouse. BB A506: BlightBan A506; concentrations of bacterial suspensions of all

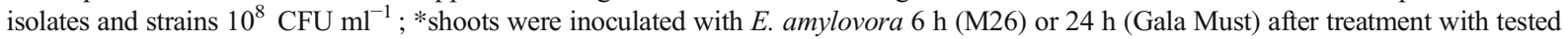
bacteria; ' 1 ' percentage of shoots infestation: the length of the shoot's necrosis in relation to its total length; data in brackets show the efficacy in \% (percentage of shoots infestation treated with the respective bacteria in comparison to control); statistical analysis was performed separately for each term; data concerning severity in columns followed by the same letter do not differ significantly according to Dunn test at $\mathrm{p}=0.05$

\section{Discussion}

The identification of tested bacterial isolates showed that five of them (L16 identified as Pseudomonas vancouverensis, $3 \mathrm{M}$ as Pseudomonas chlororaphis subsp. aureofaciens, $35 \mathrm{M}$ - Pseudomonas congelans, $43 \mathrm{M}$ - Enterobacter ludwigii, $59 \mathrm{M}$ - Pseudomonas protegens) belonged to species in which an antagonistic activity to Erwinia amylovora and a protective capacity of apple and pear against fire blight were not previously demonstrated. Bacteria of the species Pseudomonas chlororaphis were first isolated in the USA from soil on which wheat was grown for over 20 years (Weller and Cook 1983). It was proven that $P$. chlororaphis strains were capable of producing antibiotics mainly from the group of phenazines or pyoverdines, as well as a siderophore with fungal and/or bacterial pathogen suppression (Johnsson et al. 1998; Liu et al. 2007; Weller 2007; Beneduzi et al. 2012). Strain PA23 of this species protected canola (Brassica napus) from the necrotrophic fungus Sclerotinia sclerotiorum via direct antagonism (Duke et al. 2017) and hot pepper (Capsicum annum L.) from Pythium aphanidermatum. It also increased the growth of this plant seedlings in greenhouse vegetable production systems (Nakkeeran et al. 2006). Moreover, the strain O6 of $P$. chlororaphis, isolated from the roots of dryland, field-grown commercial wheat, enhances plant health and therefore it is used in agriculture as a biofertilizer and biocontrol agent (Anderson et al. 2017). On the other hand strain SR1 of $P$. chlororaphis subsp. aurantiaca has been shown to be a plant growth promoter for various crops, such as alfalfa, wheat, soybean, maize, carob, sugar cane, as well as being efficient in promoting germination and obtaining vigorous and healthy seedlings. It is currently marketed as PSA liquid from BIAGRO-BAYER Laboratory (Rosas 2017).

The first described strain of Pseudomonas vancouverensis was obtained from forest soil in Vancouver, Canada (Mohn et al. 1999). In later years, a strain of this species was isolated from the garlic rhizosphere (Mishra et al. 2008). Its fungistatic activity against Rhizoctonia solani, Fusarium oxysporum and Pythium sp. has been proven in vitro, as has its ability to biosynthesize siderophores and hydrogen cyanide (HCN). In addition, it was shown that after wheat seeds 
had been spiked with $P$. vancouverensis, the germination force was increased, as was the size of the root system or plant height (Mishra et al. 2008).

Bacteria of the species Pseudomonas congelans include a fluorescent Pseudomonads originally obtained from grass phyllosphere (Behrendt et al. 2003). Their close relationship with $P$. syringae is shown. However, there is generally no information on the potential pathogenicity of these bacteria to plants. The exception is the report on the isolation from diseased leaves and shoots of oranges of bacteria closely related to $P$. congelans (Beiki et al. 2016).

In turn, bacteria Pseudomonas protegens were isolated from tobacco, cotton and wheat on various continents. The authors of the study drew attention to the fact that this new species clustered separately from the species $P$. syringae, P. fluorescens and P. chlororaphis and additionally possessed $p h l$ and plt genes responsible for the biosynthesis of 2,4-diacetylphloroglucinol and pyoluteorin (Ramette et al. 2011). Recently strain MP12 of P. protegans was isolated from a soil sample collected in a typical warm-temperate deciduous forest near Brescia, Northern Italy (Andreolli et al. 2019). It exhibited inhibitory effects on in vitro mycelial growth of grapevine (Vitis vinifera) pathogens such as Botrytis cinerea, Alternaria alternata, Aspergillus niger, Penicillium expansum and Neofusicoccum parvum. The strain showed also activity against Phaeomoniella chlamydospora and Phaeoacremonium aleophilum, which cause very severe disease of grapevine trunks. Furthermore, MP12 strain manifested antagonism against $B$. cinerea on grapevine leaves which suggests that it could be useful as biocontrol agent for applications in viticulture. Abdelwahab et al. (2016) also isolated from agricultural land strain RhiNA with high antagonistic activity against B. cinerea, Mucor sp., A. niger and A. flavus and high efficacy against gray mold (B. cinerea) on apple fruits. It is noteworthy to mention the genetic modification of the Pf-5 strain of $P$. protegans with a genomic island (X940) encoding nitrogen fixation. Inoculation of maize and wheat with Pf-5 X940 largely improved nitrogen content and biomass accumulation in vegetative and reproductive tissues, and this beneficial effect was positively associated with high nitrogen fixation rates in roots (Fox et al. 2016).

The Enterobacter ludwigii reference strain was isolated in clinical conditions from a patient with inflammation of the urinary tract (Hoffmann et al. 2005).
However, there are reports on the BNM 0357 strain of this species, obtained from the rhizosphere of perennial ryegrass (Lolium perenne) and showing the characteristics of stimulating the growth and yield of various plants (PGPR, Shoebitz et al. 2009). In this strain, nitrogenase activity, as well as the ability to produce auxins and fungal growth limiting Fusarium solani, has been demonstrated. Gopalakrishnan et al. (2016) selected strains SRI-211 and SRI-229 of E. ludwigii showing ability to control charcoal rot disease in sorghum and plant growth-promotion in rice. When treated on seed, those strains significantly enhanced the shoot height and root length of both plant species over the un-inoculated control. Under field conditions, in both chickpea and pigeon pea, the plots inoculated with test bacteria enhanced the nodule number, nodule weight, root and shoot weights, pod number, pod weight, leaf weight, leaf area and grain yield over the un-inoculated control plots.

The other tested strains represented species known for activity against fire blight and were even active components of bio-preparations: B90 and $48 \mathrm{M}$ (Pantoea agglomerans) and $141 \mathrm{M}$ (Erwinia billingiae).

All bacterial strains used in this study, were preselected on the basis of the pear fruitlet test, which showed their high efficacy against fire blight (Mikiciński 2017). Although this test does not have a universal character, it is now considered a useful tool for a preliminary assessment of the protective action of bacteria against fire blight. However, for the initial selection of E. amylovora antagonists, many researchers used the test on agar-solidified media, and the criterion of selection was the size of the pathogen growth inhibition zone (van der Zwet et al. 2012). The results of our research indicate that after adopting a similar pattern, the strains showing satisfactory protective activity on apple blossoms and shoots could be overlooked. The in vitro test showed that, for example, strains B90, 43 M, $48 \mathrm{M}$ and $141 \mathrm{M}$ did not inhibit the growth of the pathogen on agar media but appeared to be effective in protecting apple blossoms and terminal shoots. On the other hand, strains $3 \mathrm{M}, 35 \mathrm{M}$ and $59 \mathrm{M}$ inhibited E. amylovora growth on these media, with $59 \mathrm{M}$ producing the most extensive zones on some of them. They were also effective in protecting blossoms and shoots. In search of useful isolates for disease control on pear, Aysan et al. (1999) also used an agar nutrient test, demonstrating that selected isolates were satisfactorily effective in protecting this species blossoms (52-60\%). 
Additionally, Wilson et al. (1990), immediately after screening the pool of Erwinia herbicola isolates using an in vitro test, assessed the protective efficacy of the most active isolates on the blossoms and hawthorn shoots, stating very high efficacy $(80 \%)$ of one of the selected isolates. It is worth noting the results of our study showing that the in vitro test can reveal the properties of inhibiting the growth of a pathogen by a given strain on one medium but stimulating its growth on another (e.g., medium 925). This indicates that medium composition determines the antagonistic activity of bacteria. The in vitro test can therefore be useful to study the potential biotic relationships between bacteria in the model system, but for screening them for use in biological control, it is better to apply selected plant organs, such as pear fruitlets. Notably, McLaughlin and Roberts (1993) distinguished among the approximately 400 tested bacterial isolates by screening pear fruitlet slices for a group of satisfactorily effective isolates for the protection of pear blossoms. Thus, Ülke and inar (1999) and Gerami et al. (2013) concluded that in addition to the compatibility with the efficacy of selected bacterial isolates by different methods, a clear lack of a relationship between antagonistic activity on artificial media and protective activity on blossoms or shoots of E. amylovora host plants was found. In this context, it is worth emphasizing the opinion of Lindow (1988) that the in vitro test is not credible enough to select potential antagonists. Beer et al. (1984) noted that bacteria suppressing the growth of E. amylovora in vitro are often not able to activate this mechanism in planta. It should be assumed that the rich composition of microbiological media, which were often used by various researchers, could mobilize bacteria to produce substances toxic to E. amylovora, while in their natural environment, these bacteria may simply not have substrates for their production.

In all experiments of our own studies on apple 'Idared' trees, the protective abilities of the tested bacteria (two strains of Pantoea agglomerans and one strain each of the species Enterobacter ludwigii, Erwinia billingiae, Pseudomonas vancouverensis, $P$. chlororaphis subsp. aureofaciens, P. congelans, and P. protegens) on blossoms were at the level of medium to high depending on the experiment (55-93\%, according to assessment 9 days after inoculation), and they did not differ significantly among themselves in individual experiment. Additionally, experiments on detached apple branches of the cvs. Linda and Jonagored confirmed the satisfactory efficacy of the tested strains, which was similar to or even higher than that of the copper product used for comparison. Due to the quarantine status of E. amylovora, all experiments were carried out in greenhouse conditions, i.e., high air humidity, close to optimal temperature and a high concentration of the pathogen inoculum. In turn, Kearns and Hale (1993) showed the high efficacy of $P$. agglomerans strain Eh1087 in protecting blossoms on apple trees in a greenhouse if the treatment was performed immediately after blossom development or mid-flowering; the efficacy ranged from 70 to $80 \%$. However, the efficacy of the treatment at the end of flowering was lower and amounted to only $36 \%$. Noteworthy is relatively low levels of disease severity in some of our assays, especially those in flowers from detached apple branches. One of the reasons could be different age of flowers at the time of inoculation (full bloom) and the inoculation method used, i.e. spraying and not introducing the exact amount of inoculum on each flower. The results of detailed experiments carried out by Gouk and Thomson (1999) and Pusey and Smith (2008) seem to explain the reason for this phenomenon. It was found that the blossoms are most susceptible to infection up to 3 days old. Pusey and Smith (2008) conducted experiments in field conditions in which they inoculated apple blossoms at different times from the opening of the bud and found that the percentage of their infection decreased with age. Taylor et al. (2003) detected disease symptoms only when total levels of E. amylovora per apple blossom exceeded $10^{6} \mathrm{CFU}$ within 4 days after budburst. It seems that in our case the number of bacteria introduced on particular flower was smaller. It is also possible that because the branches came from the orchard, the flowers may have been colonized by other bacteria that may have limited the survival of E. amylovora. The study of Pusey et al. (2009) provided detailed information about the colonization, growth, and identity of culturable, indigenous bacteria and yeasts on apple blossoms and found that among numerous isolates representing most of the taxa identified the antagonists to E. amylovora were present. The susceptibility of blossoms may also be related to their anatomical structure. Experiments show that larger cells of nectaries are less susceptible to fire blight than are the smaller cells (Farkas et al. 2006).

Among the other bacterial species studied, Erwinia billingiae strains Eb660 and Eb661 revealed high abilities to protect against fire blight in pear fruitlets and apple blossoms (Jakovljevic et al. 2006). Bacteria of this 
species were first described in 1999 by Belgian researchers (Mergaert et al. 1999) who included in their taxonomic studies strains previously obtained by Billing and Baker (1963). Before reclassification to E. billingiae, the phenotypic characteristics of these strains allowed classification into the species Erwinia herbicola (syn. Pantoea agglomerans). In the present study, in the group of bacteria showing medium to high efficacy (from 55 to $88 \%$ ), there was also strain $43 \mathrm{M}$ (Enterobacter ludwigii), whose characteristic feature was the lack of ability to biosynthesize yellow pigment. Strains belonging to the same species and having the same phenotypic traits were also isolated from hawthorn flowers and leaves (Wilson et al. 1990).

In studies assessing the bacterial ability to protect apple shoots on M.26 rootstock, the highest efficacy was observed for Pseudomonas congelans (35 M, efficacy 96\%), Enterobacter ludwigii (43 M - efficacy 93\%) and P. agglomerans (48 $\mathrm{M}-92 \%)$. In this experiment, relatively low efficacy $(55 \%)$ was demonstrated by the BlightBan A506 biopreparation. This could be due to the lower concentration of the active agent in its working liquid compared to the aqueous suspensions of the test bacteria. Preparing the BlightBan A506 suspension according to the working instructions resulted in a concentration of $10^{7} \mathrm{CFU} \mathrm{ml}{ }^{-1}$ (Stockwell and Stack 2007), while it should be noted that the aqueous suspensions of the tested strains had a concentration of $10^{8} \mathrm{CFU} \mathrm{ml} \mathrm{m}^{-1}$. Additionally, the date of application $6 \mathrm{~h}$ before infection was not 'beneficial' for this treatment because Wilson and Lindow (1993) proved that A506 is the most effective after application $72 \mathrm{~h}$ before inoculation and the main mechanism of its competition for the place. In addition, Vanneste et al. (2006) found that the bacterial population of this strain is drastically reduced after $7 \mathrm{~h}$ of application on some apple organ surfaces, e.g., flowers. In experiments on the 'Gala Must' trees, this interval was extended from preventive treatment to $24 \mathrm{~h}$, which resulted in increased efficacy not only for A506 but also for all tested strains. All strains assessed showed $100 \%$ efficacy. A similar relationship was observed by Ülke and nar 1999, who carried out an assessment of the efficacy of P. agglomerans on pear shoots. Extending the interval between treatments resulted in a significant increase in the effectiveness of protective bacteria.

In the literature, however, there are only few reports devoted to assessing the protective capacity of bacteria on apple shoots, carried out according to the method used in our studies, i.e., cutting off the tips of shoots and then applying to the wound of the test bacteria and inoculation with the pathogen. Similar research has been performed, including by Galasso et al. (2002), who estimated protective capacities of two strains belonging to the genus Pseudomonas on the leaves of actively growing apple shoots in greenhouse conditions. The experiment was performed in such a way that the shoots were first sprayed with suspensions of the test bacteria, and after $24 \mathrm{~h}$, the top leaves were wounded and inoculated with E. amylovora suspension. The efficacy of bacteria was characterized by high variability ranging from 40 to $87 \%$. Similar experiments were also carried out by Spanish researchers who, in controlled conditions, injured the main veins of apple leaves, protectively treated them with test bacteria and then inoculated them with E. amylovora. The EPS62e P. fluorescens isolate showed high efficiency (90\%), and Lactobacillus plantarum isolates protected $28 \%$ to $68 \%$ of leaves (Roselló et al. 2013).

On the other hand, Hungarian researchers comprehensively studied the P. agglomerans strain HIP32 (Hevesi et al. 2006) in greenhouse conditions (Hevesi et al. 2006). The experiment consisted of introducing on the leaves of six apple cultivars first to an aqueous suspension of this strain and then to a suspension of E. amylovora or vice versa. The efficacy of the test bacteria in the first variant was from 66 to $98 \%$, while where the pathogen was first applied, it ranged from 34 to $51 \%$. Wilson et al. (1990) also conducted studies on hawthorn shoots with bacteria of the species $P$. agglomerans and P. syringae. Actively growing shoots, however, were not injured, and suspensions of both antagonistic bacteria and the pathogen were applied in the form of spraying. The authors noted high efficacy of all tested strains protecting hawthorn, to the same extent as streptomycin used for comparison.

In conclusion, our research showed the presence on apple leaves and in soil environments of bacteria belonging to the species for which biocontrol activity against fire blight is recognized for the first time. Until now in the studies of other authors such activity by representative strains of those species has been found only against plant diseases caused by fungi. One of the important challenges for commercialization of the biological method is variability in the efficacy of the control. It can be related to the environmental conditions and pathogen inoculum potential present in particular biotop. Also the formulation of biocontrol agent, 
method and term of its application can be crucial. We believe that the future of the biological method lies in the development of a strategy for its integration with other currently available methods. The suitability of biopreparations is primarily seen at low or at most medium risk of disease and in crops cultivated within an ecological system. Some of the selected strains, e.g. $43 \mathrm{M}$, $59 \mathrm{M}$, have a perspective of practical application, but more research, e.g. ecological, biotechnological, would be needed.

Acknowledgements The authors wish to express their thanks for kind providing the reference strains used in this study: to dr. Virginia O. Stockwell (Oregon State University, Corvallis, USA) strains A506 and C9-1. We are also thankful to dr. Virginia O. Stockwell for bio-preparation BlightBan A506. The help in statistical elaboration of the results of prof. Robert Maciorowski and the technical help of Mrs. Danuta Rasz-Zając and Mrs. Dominika Niedzielska is greatly appreciated.

Conflict of interest The authors have no conflicts of interest to declare.

Compliance with ethical standards This article does not contain any study with human participants or animals performed by the authors.

Open Access This article is distributed under the terms of the Creative Commons Attribution 4.0 International License (http:// creativecommons.org/licenses/by/4.0/), which permits unrestricted use, distribution, and reproduction in any medium, provided you give appropriate credit to the original author(s) and the source, provide a link to the Creative Commons license, and indicate if changes were made.

\section{References}

Abdelwahab, R., Bensidhoum, L., Tabli, N., Bouaoud, Y., Naili, F., Cristina, C.,Nabti, E. (2016). A Pseudomonas protegens with high antifungal activity protects apple fruits against Botrytis cinerea gray mold. International Journal of Scientific Research in Science and Technology, 2(6), 227237. Print ISSN: 2395-6011 | online ISSN: 2395-602X.

Anderson, A. J., Ryong, K. B., \& Cheol, K. Y. (2017). The Gac/ Rsm signaling pathway of a biocontrol bacterium, Pseudomonas chlororaphis O6. Research in Plant Disease, 23(3), 212-227.

Andreolli, M., Zapparolia, G., Angelinib, E., Lucchettab, G., Lampisa, G., \& Vallinia, G. (2019). Pseudomonas protegens MP12: A plant growth-promoting endophytic bacterium with broad-spectrum antifungal activity against grapevine phytopathogens. Microbiological Research, 219, 123-131.

Aysan, Y., Tokgonul, S., Cinar, O., \& Kuden, A. (1999). Biological, chemical, cultural control methods and determination resistant cultivars to fire blight in pear orchards in the eastern Mediterranean region of Turkey. Acta Horticulturae, 489, 549-552.

Bahadou, S. A., Ouijja, A., Karfach, M. A., Tahiri, A., \& Lahlali, R. (2018). New potential bacterial antagonists for the biocontrol of fire blight disease (Erwinia amylovora) in Morocco. Microbial Pathogenesis, 117, 7-15.

Beer, S. V., Rundle, J. R., \& Wodzinski, R. S. (1984). Interaction between Erwinia amylovora and Erwinia herbicola in vitro, in immature pear fruits and in apple blossoms. Acta Horticulturae, 151, 203-204.

Behrendt, U., Ulrich, A., \& Schumann, P. (2003). Fluorescent pseudomonads associated with the phyllosphere of grasses; Pseudomonas trivialis sp. nov., Pseudomonas poae sp. nov. and Pseudomonas congelans sp. nov. International Journal of Systematic and Evolutionary Microbiology, 53, 14611469.

Beiki, F., Busquets, A., Gomila, M., Rahimian, H., Lalucat, J., \& García-Valdés, E. (2016). New Pseudomonas spp. are pathogenic to citrus. PLoS One, 11(2), e0148796. https://doi. org/10.1371/journal.pone.0148796.

Beneduzi, A., Ambrosini, A., \& Passaglia, L. M. P. (2012). Plant growth-promoting rhizobacteria (PGPR): Their potential as antagonists and biocontrol agents. Genetics and Molecular Biology, 35(4 Suppl), 1044-1051.

Billing, E., \& Baker, L. A. E. (1963). Characteristics of Erwinialike organisms found in plant material. Journal of Applied Bacteriology, 26, 58-65.

Cabrefiga, J., Francés, J., Montesinos, E., \& Bonaterra, A. (2011). Improvement of fitness and efficacy of a fire blight biocontrol agent via nutritional enhancement combined with osmoadaptation. Applied and Environmental Microbiology, 77, 3174-3181.

Carlone, G. M., Valadez, M. J., \& Pickett, M. J. (1982). Methods for distinguishing gram-positive from gram-negative bacteria. Journal of Clinical Microbiology, 16, 1157-1159.

Dell Inc. (2016). Dell Statistica (data analysis software system), version 13. software.dell.com.

Drancourt, M., Bollet, C., \& Raoult, D. (1997). Stenotrophomonas africana sp. nov., an opportunistic human pathogen in Africa. International Journal of Systematic Bacteriology, 47, 160163.

Duke, K. A., Becker, M. G., Girard, I. J., Millar, J. L., Dilantha, W. G., Belmonte, F. M. F., \& de Kievit, T. R. (2017). The biocontrol agent Pseudomonas chlororaphis PA23 primes Brassica napus defenses through distinct gene networks. BMC Genomics, 18, 467. https://doi.org/10.1186/s12864017-3848-6.

Farkas, Á., Orosz-Kovács, Z., \& Bubán, T. (2006). Nectary structure of pear cultivars and its relation to fire blight susceptibility. Acta Horticulturae, 704, 131-138.

Fox, A. R., Soto, G., Valverde, C., Russo, D., Lagares Jr., A., Zorreguieta, A., Alleva, K., Pascuan, C., Frare, R., MercadoBlanco, J., Dixon, R., \& Ayub, N. D. (2016). Major cereal crops benefit from biological nitrogen fixation when inoculated with the nitrogen-fixing bacterium Pseudomonas protegens Pf-5 X940. Environmental Microbiology, 18(10), 3522-3534.

Fried, A., Schell, E., Moltman, E., \& Wensing, A. (2013). Control of fire blight in Baden-Württenberg at the end of the streptomycin era. Acta Horticulturae, 1056, 55-56. 
Galasso, O., Sponza, G., Bazzi, C., \& Vanneste, J. L. (2002). Characterisation of two fluorescent strains of Pseudomonas as biocontrol agents against fire blight. Acta Horticulturae, 590, 299-307.

Gerami, E., Hassanzadeh, N., Abdollahi, H., Ghasemi, A., \& Heydari, A. (2013). Evaluation of some bacterial antagonists for biological control of fire blight disease. Journal of Plant Pathology, 95, 127-134.

Gopalakrishnan, S., Vadlamudi, S., Samineni, S., \& Kumar, C. V. S. (2016). Plant growth-promotion and biofortification of chickpea and pigeonpea through inoculation of biocontrol potential bacteria, isolated from organic soils. Springerplus., 5(1), 1882. https://doi.org/10.1186/s40064-016-3590-6.

Gouk, S. C., \& Thomson, S. V. (1999). Influence of age apple flowers on growth of Erwinia amylovora. Acta Horticulturae, 489, 525-527.

Hevesi, M., El-Arabi, K., Göndör, M., Papp, J., Honty, K., Kása, K., \& Tóth, M. (2006). Development of eco-friendly strategies for the control of fire blight in Hungary. Acta Horticulturae, 704, 345-348.

Hoffmann, H., Stindl, S., Stumpf, A., Mehlen, A., Monget, D., Heesemann, J., Schleifer, K. H., \& Roggenkamp, A. (2005). Description of Enterobacter ludwigii sp. nov., a novel Enterobacter species of clinical relevance. Systematic and Applied Microbiology, 28, 206-212.

Jakovljevic, V., Du, Z., Jock, S., \& Geider, K. (2006). Epiphytic Erwinias to control fire blight. Acta Horticulturae, 704, 289292.

Janse, J. D. (2005). Phytobacteriology, principles and practice. Wallingford: CABI Publishing. 360p.

Johnson, K. B., \& Stockwell, V. O. (2000). Biological control of fire blight. In J. L. Vanneste (Ed.), Fire blight - The disease and its causative agent, Erwinia amylovora (pp. 319-337). Wallingford: CAB International.

Johnsson, L., Hökeberg, M., \& Gerhardson, B. (1998). Performance of the Pseudomonas chlororaphis biocontrol agent MA 342 against cereal seed-borne diseases in field experiments. European Journal of Plant Pathology, 104, $701-711$

Kado, C. I. (1979). Methods in plant bacteriology (p. 80). Davis: University of California.

Kearns, L. P., \& Hale, C. N. (1993). Biological control of fire blight by Erwinia herbicola: Survival of applied bacteria in orchard and glasshouse trials. Acta Horticulturae, 338, 333339.

Lelliott, R. A., \& Stead, D. E. (1987). Methods for the diagnosis of bacterial diseases of plants. Oxford: Blackwell Scientific Publications.

Lindow, S. E. (1988). Lack of correlation of in vitro antibiosis with antagonism of ice nucleation active bacteria on leaf surfaces by non-ice nucleation active bacteria. Phytopathology, 78, 444- 450.

Liu, H., He, Y., Jiang, H., Peng, H., Huang, X., Zhang, X., Thomashow, L. S., \& Xu, Y. (2007). Characterization of a phenazine-producing strain Pseudomonas chlororaphis GP72 with broad-spectrum antifungal activity from green pepper rhizosphere. Current Microbiology, 54, 302-306.

McGrath, M. J., Koczan, J. M., Kennelly, M. M., \& Sundin, G. (2009). Evidence that prohexadion-calcium induces structural resistance to fire blight infection. Phytopathology, 99, 591596.
McLaughlin, R. J., \& Roberts, R. G. (1993). Laboratory and field assays for biological control of fire blight in d'Anjou pear. Acta Horticulturae, 338, 317-319.

Mergaert, J., Hauben, L., Cnockaert, M. C., \& Swings, J. (1999). Reclassification of non-pigmented Erwinia herbicola strains from trees as Erwinia billingiae sp. nov. International Journal of Systematic Bacteriology, 49, 377-383.

Mikiciński, A. (2017). Bacteria and resistance inducers in control of apple against fire blight (Erwinia amylovora). $\mathrm{PhD}$ Thesis Institute of Horticulture, Skierniewice, Poland, 218p.

Mikiciński, A., Sobiczewski, P., Puławska, J., \& Maciorowski, R. (2016). Control of fire blight (Erwinia amylovora) by a novel strain 49M of Pseudomonas graminis from the phyllosphere of apple (Malus spp.). European Journal of Plant Pathology, 145, 265-276.

Mishra, P. K., Mishra, S., Selvakumar, G., Bisht, S. C., Bisht, J. K., Kundu, S., \& Gupta, H. S. (2008). Characterisation of a psychrotolerant plant growth promoting Pseudomonas sp. strain PGERs17 (MTCC 9000) isolated from North Western Indian Himalayas. Annals of Microbiology, 58, 561-568.

Mohn, W. W., Wilson, A. E., Bicho, P., \& Moore, E. R. B. (1999). Physiological and phylogenetic diversity of bacteria growing on resin acids. Systematic and Applied Microbiology, 22, 6878.

Nakkeeran, S., Kavitha, K., Chandrasekar, C., Renukadevi, P., \& Fernando, W. G. D. (2006). Induction of plant defence compounds by Pseudomonas chlororaphis PA23 and Bacillus subtilis BSCBE4 in controlling damping-off of hot pepper caused by Pythium aphanidermatum. Biocontrol Science and Technology, 16(4), 403-416.

Norelli, J. L., Jones, A. L., \& Aldwinckle, H. S. (2003). Fire blight management in the twenty-first century. Plant Disease, 87(7), 756-765.

Psallidas, P. G., \& Tsiantos, J. (2000). Chemical control of fire blight. In J. L. Vanneste (Ed.), Fire blight. The Disease and its Causative Agent, Erwinia amylovora (199-234). Wallingford: CABI Publishing.

Pusey, P. L. (1999). Water relations and infection by Erwinia amylovora based on crab apple blossom model. Acta Horticulturae, 489, 521-524.

Pusey, P. L., \& Smith, T. J. (2008). Susceptibility of apple hypanthium to Erwinia amylovora in relation to flower age and cougarblight model. Acta Horticulturae, 793, 45-51.

Pusey, P. L., Stockwell, V. O., \& Mazzola, M. (2009). Epiphytic bacteria and yeasts on apple blossoms and their potential as antagonists of Erwinia amylovora. Phytopathology, 99, 571581.

Ramette, A., Frapolli, M., Fischer-Le Saux, M., Gruffaz, C., Meyer, J. M., Défago, G., Sutra, L., \& Moënne-Loccoz, Y. (2011). Pseudomonas protegens sp. nov., widespread plantprotecting bacteria producing the biocontrol compounds 2,4diacetylphloroglucinol and pyoluteorin. Systematic and Applied Microbiology, 34, 180-188.

Reasoner, D. J., \& Geldreich, E. E. (1985). A new medium for the enumeration and subculture of bacteria from potable water. Applied and Environmental Microbiology, 49, 1-7.

Rosas, S. B. (2017). Pseudomonas chlororaphis subsp. aurantiaca SR1: Isolated from rhizosphere and its return as inoculant. International Biology Review, 1(3), 1-19. 
Roselló, G., Bonaterra, A., Francés, J., Montesinos, L., Badosa, E., \& Montesinos, E. (2013). Biological control of fire blight of apple and pear with antagonistic Lactobacillus plantarum. European Journal of Plant Pathology, 137, 621-633.

Schaad, N. W., Jones, J. B., \& Chun, W. (2001). Laboratory guide for identification of plant pathogenic bacteria. St. Paul: APS Press. 373p.

Shoebitz, M., Ribaudo, C. M., Pardo, M. A., Cantore, M. L., Ciampi, L., \& Curá, J. A. (2009). Plant growth promoting properties of a strain of Enterobacter ludwigii isolated from Lolium perenne rhizosphere. Soil Biology and Biochemistry, $41,1768-1774$.

Sobiczewski, P. (2011). Integrated management of fire blight (Erwinia amylovora) on apple and pear. Rastenievüdni nauki (Plant science). Bulgaria, 48, 6-13.

Sobiczewski, P., \& Bubán, T. (2004). The effect of Regalis ${ }^{\circledR}$ (prohexadione calcium) on the reduction of fire blight (Erwinia amylovora) severity in apple trees. International Journal of Horticultural Science, 10, 61-66.

Sobiczewski, P., \& Millikan, D. F. (1985). Efficacy of chemicals for control of fire blight (Erwinia amylovora). Fruit Science Reports, 12, 27-34.

Sobiczewski, P., Peil, A., Mikiciński, A., Richter, K., Lewandowski, M., Żurawicz, E., \& Kellerhals, M. (2015). Susceptibility of apple genotypes from European genetic resources to fire blight (Erwinia amylovora). European Journal of Plant Pathology, 141, 51-62.

Steiner, P. W. (2000). Integrated orchard and nursery management for the control of fire blight. In J. L. Vanneste (Ed.), Fire blight: The disease and its causative agent, Erwinia amylovora (pp. 339-358). Wallingford: CABI Publishing.

Stockwell, V. O., \& Duffy, B. (2012). Use of antibiotics in plant agriculture. Scientific and Technical Review of the Office International des Epizooties, 31, 199-210.

Stockwell, V. O., \& Stack, J. P. (2007). Using Pseudomonas spp. for integrated biological control. Phytopathology, 97, 244 249.

Taylor, R. K., Hale, C. N., Hennshall, W. R., Armstrong, J. L., \& Marchal, J. W. (2003). Effect of inoculum dose on infection of apple (Malus domestica) flowers by Erwinia amylovora. · New Zealand Journal of Crop and Horticultural Science, 31(4), 325-333.

Thomson, S. (2000). Epidemiology of fire blight. In J. L. Vanneste (Ed.), Fire blight: The disease and its causative agent, Erwinia amylovora (pp. 9-36). Wallingford: CABI Publishing.

Ülke, G., \& inar, Ö. (1999). Biological control studies on fire blight caused by Erwinia amylovora (Burr.) Winslow et al. Acta Horticulturae, 489, 611-614.

van der Zwet, T., Orolaza-Halbrendt, N., \& Zeller, W. (2012). Fire blight. History, biology and management. St. Paul: APS Press. $421 \mathrm{p}$.

Vanneste, J. (2000). What is fire blight? What is Erwinia amylovora? How to control it? In J. L. Vanneste (Ed.), Fire blight: The disease and its causative agent, Erwinia amylovora (pp. 1-6). Wallingford: CABI Publishing.

Vanneste, J. L., Cornish, D. A., Yu, J., \& Spinelli, F. (2006). Establishment and survival on apple and pear leaves of four biological control agents including Pantoea agglomerans P10c and Pseudomonas fluorescens A506. Acta Horticulturae, 704, 307-311.

Weisburg, W. G., Barns, S. M., Pelletier, D. A., \& Lane, D. J. (1991). 16S ribosomal DNA amplification for phylogenetic study. Journal of Bacteriology, 173, 697-703.

Weller, D. M. (2007). Pseudomonas biocontrol agents of soilborne pathogens: Looking back over 30 years. Phytopathology, 97, 250-256.

Weller, D. M., \& Cook, R. J. (1983). Suppression of take-all of wheat by seed treatments with fluorescent pseudomonads. Phytopathology, 73, 463-469.

Wilson, M., \& Lindow, S. E. (1993). Interactions between the biological control agent Pseudomonas fluorescens strain A506 and Erwinia amylovora in pear blossoms. Phytopathology, 83, 117-123.

Wilson, M., Epton, H. A. S., \& Sigee, D. C. (1990). Biological control of fire blight of hawthorn (Crataegus monogyna) with Erwinia herbicola under protected conditions. Plant Pathology, 39, 301-308. 